\title{
複合材料の設計と評価の最前線
}

\author{
4. 疲 労 ${ }^{\dagger}$
}

一短繊維強化プラスチックスの疲労特性—

一一組み合わせ応力下における疲労特性——

岩 本 正治* 藤 井透**

\section{Design and Evaluation Frontiers of Composite Materials}

IV : Fatigue

Fatigue of Short Fiber Reinforced Plastics

_ Fatigue under Biaxial and Multiaxial Loading _

by

Masaharu Iwamoto* and Toru FuJII**

Key words : Fatigue, Polymer matrix composites, Short fiber, Crack growth, Bi-axial stress, Multi-axial stress

\section{1 は じめ に}

高分子を樹脂とする繊維強化複合材料（以下，FRP） の疲労破壊過程は金属材料のそれとは大きく異なり，金 属材料に対する知識を FRP の疲労破壊に当てはめるこ とは適切でない，設計にあたっては，FRP 独特の疲労 破壊特性と破壊メカニズムを理解する必要がある.

70年代初期, Dew-Hughes と Way は GFRP の疲労 について概説している. Salkind も多くの疲労デー夕を 集めて疲労に関するレビューを著している. Hahn は疲 労挙動と寿命予測に対しての多くの文献を調査し, その 結果をまとめている゙. 最近, マイクロメカニクスと損傷 蓄積の観点から疲労を扱った研究, また, FRP の損傷 進展過程に対する一般的な疲労特性に関する研究などが 多く報告されている. 統計的手法を用いて巨視的観点か ら疲労寿命予測も幅広く試みられている.

このように,FRPの疲労に関して, 体系的に理解さ れた感があるが, これまでの研究の多くは, 連続繊維系 FRP を対象としたり，また，単軸荷重が材料に負荷さ れた場合に限られている. 高性能母材樹脂の開発と共に, 短繊維系 FRP でも, 高い強度特性が発揮でき, 一次構 造部材への適用も可能になりつつある. また, 構造部材 では引張りや圧縮荷重が単純に作用すると考えるより， 2 軸以上の複雑な応力が作用するのが実際的である. そ こで, 本講座では FRP の疲労に関して以下の二つの話 題を取り上げ，解説する.

(1) 短繊維強化プラスチックスの疲労特性

(2) 組み合わせ応力下における疲労特性

\section{2 短繊維強化プラスチックスの疲労特性}

FRP は, 強化繊維の長さにより連続緎維強化と短緎

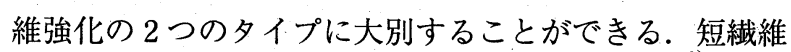
の長さは, 成形法や要求する特性によって異なる。例え ば SMC 成形法で用いられるチョップドストランドでは 通常 $25 \mathrm{~mm}$ であるが, 比較的高い引張強さを要求する 場合は $50 \mathrm{~mm}$, 複雑な形状で充塡の難しいリブ, ボスの ある場合は $12.5 \mathrm{~mm}$ 程度である. また, BMC 成形法で は, 繊維長は SMC で用いられるよりも短く通常 $6 \mathrm{~mm}$ 程度である. 射出成形法では, SMC ゃ BMC 成形法と は異なり, 纎維と樹脂が一体となったチップを成形機に 投入し, 機内部のスクリュウにより高温下で混練, 金型 に射出されるまでのこの工程において, 繊維長は初期の チップ時よりも短くなり, ある繊維長分布を持つ. その 平均繊維長は通常 $1 \mathrm{~mm}$ 以下である.

ここで, 連続繊維と短繊維のそれぞれにより形成され たFRP の不利な点, 有利な点を比較し, 列挙する. 連 続繊維系と比べて短㵶維系 FRP の不利な点は, (1)繊維 端をもつ, (2)繊維方向での弾性率や強度が本質的に劣る, (3)通常, 䋊維方向が負荷方向に対して垂直な場合を除き 連続繊維系よりもノッチ敏感性である, (4)チョップドス トランドでは，種々の特性に幅広いバラッキを生じ，射 出成形では, 繊維長さと配向において, 制御が困難, な どが挙げられる。しかし, 有利な点もあり, 短纎維系 FRP が自動車用部品や家電製品など, 種々の工業製品 に応用されている. その理由は, (1)複雑な形状部品の成 形加工が可能で, 比較的安価, (2)高い生産性, 自動化可, 


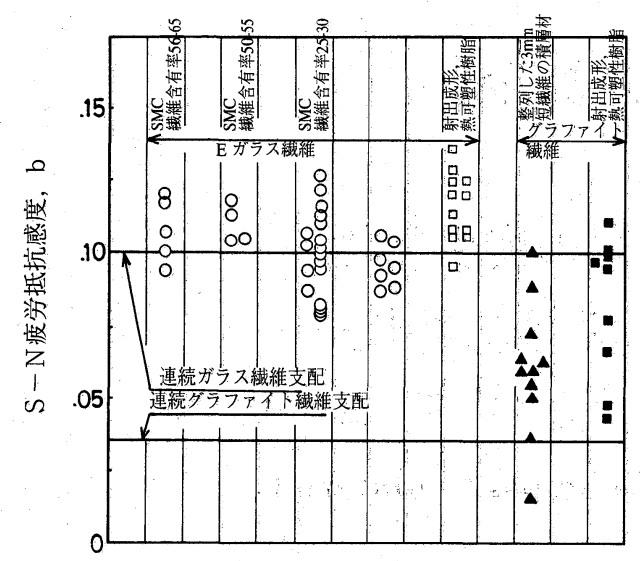

図 1 短繊維複合材に打ける $S-N$ 引張疲労抵抗感度

(3)平面で等方性の性質をもつ, (4)種々の高性能熱可塑性 樹脂は母材として利用でき, 幅広い力学的, 熱的, 環境 特性に提供可，などである。ここでは，短絾維系 FRP が工業材料として幅広く利用されるにあたり，種々の力 学的特性のなかで, 特に重要な繰返し数依存型挙動であ る疲労に関する研究に注目して解説する。

\section{$2 \cdot 1$ 平滑試験片の $S-N$ 特性}

通常, $S-N$ 曲線は, 縦軸に繰返し負荷応力振幅 $S$ を 真数で, 横軸に破断までの全繰返し数 $N$ を対数で示す. 図 1 は, 64 個の公表された $\mathrm{E}$ ガラス繊維強化の SMC (纎維含有率. $65 \sim 25 \mathrm{wt} \%$ ), CSM (Chopped Strand Mat), INJ. MLD. (Injection-Mold) およびグラファイト 瀻維強化の INJ. MLD. の応力比 $R=0.0 \sim 0.1$, 荷重制 御試験, 正弦波, 各繰返し速度下での文献デー夕（熱的 破損したものを除いた）を基に，短瀻維系 FRP の疲労 寿命評価を疲労抵抗感度を意味する $b$ で整理したもの である゙、ここに, bは， $S-N$ 曲線の縦軸を繰返しの最 大応力 $S$ あるいは応力振幅 $\Delta S$ を静的強度 $S_{0}$ てて無次元 化し, 横軸の $N$ との関係の片対数表示において, 直接 関係すなわち次式(1)のように示される，そのときの直線 の傾きを表し, 大抵の短瀻維系 FRP は破断繰返し数 $N$ が $10^{5}$ までは式(1)で示される.

$$
S / S_{0}=1-b \log N
$$

図中には，一方向連続ガラス瀻維およびグラファイト繊 維の場合のそれぞれ $b=0.10$ および $b=0.035$ が示され ている.この図から，何机の瀻維拉よび成形法に执いて も連続緎維のデー夕に接近七, 破損は連続繊維強化積層 材と同程度の範囲内であることを示唆していることがわ かる。 ガラス短䋐維系 FRP の引張疲労強度は, 最初の 10 繰返し数で静的強度の $9 \sim 13 \%$ 減の強度を示し, ま た，これを炭素纎維系と $\mathrm{b}$ で比較すると, 炭素繊維系 の方が小さい，すなわち疲労特性が優れていることもわ かる.

その他の $S-N$ 挙動の研究として, PEEK, PES, PA6, PA66 などの熱可塑性プラスチックスにガラス (30 $\sim 20 \mathrm{wt} \%)$ や炭素短緎維 $(20 \sim 15 \mathrm{wt} \%)$ で強化された種 々のFRTP (Fiber Reinforced Thermo-Plastics) 材の平 面曲げ疲労強度に及ぼす繊維配向の影響の研究では, 樹
脂の痩労強度が高いものほど瀻維の強化効果は低いこと や瘦労強度は繊維の配向に起因した異方性が顕著である ことや，またガラス短瀻維強化ポリカーボネイト射出成 形材の片振り引張りと曲げ度労強度に及ぼすウエルドラ インの影響の研究では, 両試験ともウエルドライン有り の疲労強度は無しの約 $1 / 20$ の寿命であること, $\mathrm{E}$ およ びECR ガラスの CSM 強化ビスフェノール材の室温お よび $80^{\circ} \mathrm{C}$ 下に抢ける疲労強度に及ぼす環境（蒸留水, 硫酸, 水酸化ナトリウム水溶液, エタノール, ベルクロ ロエチレン, 石油) の影響の研究では, 酸による影響が 最も大きいことなどがある，他に，CFRTP の平滑材 と切久き材の回転曲げ疲労強度, 瀻維含有率と繊維配向 および繰返し速度の影響などもある。

次に, 通常の $S-N$ 曲線に拝いてバラッキの大きい材 料では, 同一応力レベル上にデータが広範囲に分布し, 統計的手法を用いても評価が困難になる. そこで, 疲労 特性のバラツキが，例えば試料内部のクレーズのような 欠陌等により生じると考え, クレーズ欠陥の有無の 2 種 類の試料を作成し，欠陥の有した試験片では初期たわみ が大きくなる特性に着目して $\delta_{0}-N$ 曲線を求めて検討し た疲労特性評価法の一例を紹介する゙。 $S-N$ 曲線と $\delta_{0}-N$ 曲線の両者のデータのバラッキを比 較すると後者が小さくなり，また両軸とも特性値をとっ ているために応力レベルに関係なく $\delta_{0}$ の大きい試験片 は疲労寿命は短くなる傾向を示すことを確認, 欠陥によ る試験片のバラッキがあっても疲労寿命を正確に評価で きるとしている.この具体的な試料および負荷試験法は, ガラス繊維強化不飽和ポリエステル SMC 材のガラス含 有率が高く充填材を含まない高強度 SMC とガラス含有 率があまり高くなく充填材を多く含む一般 SMCであり, 両振り平面 4 点曲げ度労特性試験によるものである.

\section{$2 \cdot 2$ 疲労き裂伝ば挙動}

先の $S-N$ 挙動から得られる情報は, ある応力振幅下 での最終破断時間とその疲労限である. このデータは， 疲労強度設計の観点から重要であるが，さららる信頼性， 安全性を考える場合, 疲労破壊のメカニズムの情報を必 要である. 通常, 破損は, 累積損傷あるいは巨視的疲労 き裂の発生と成長によって起こる. 累積損傷は母材樹脂 の延性や繊維/樹脂界面などの特性に支配され，またき 裂の成長挙動においては累積損傷と関連し, き裂成長速 度がより遅ければ, より安全であることは言うまでもな い. そこで, 短繊維系 FRP の疲労き裂伝ぱに支配され た破損に関して破壊力学的研究の観点から解説する.

まず，短纎維系 FRP の疲労き裂伝ぱ挙動への破壊力 学の適合性を検討した結果の一例を示す：ガラス CSM (30wt\%) 強化不飽和ポリエステル材の引張疲労き裂伝 ば挙動の研究に泣拉いて, 強化基材が CSMのように比較 的瀻維長が長い場合, 図 2 に示すように, 疲労き裂先端 の繰返しによる累積損傷によりき裂先端が不明膫となり， 基礎デー夕となる時々刻々測定される疲労き裂進展量の 評価方法が問題となる。この評価法として, コンプライ アンス法が有効である：図 3 は，縦軸に疲労き裂伝ぱ速 


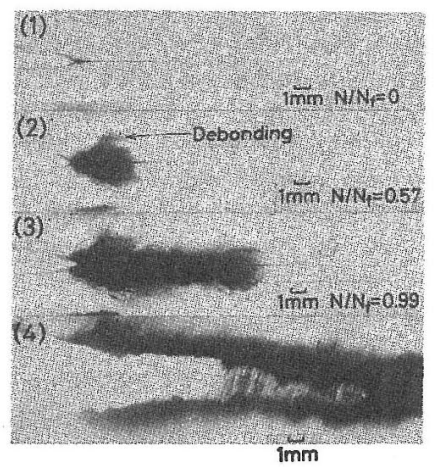

図 2 CSM 材の疲労き裂進展過程におけるノッチ先 端での巨視的損傷様相 $\left(\sigma=5.3 \mathrm{MPa}, N_{f}=716\right.$ cycles)

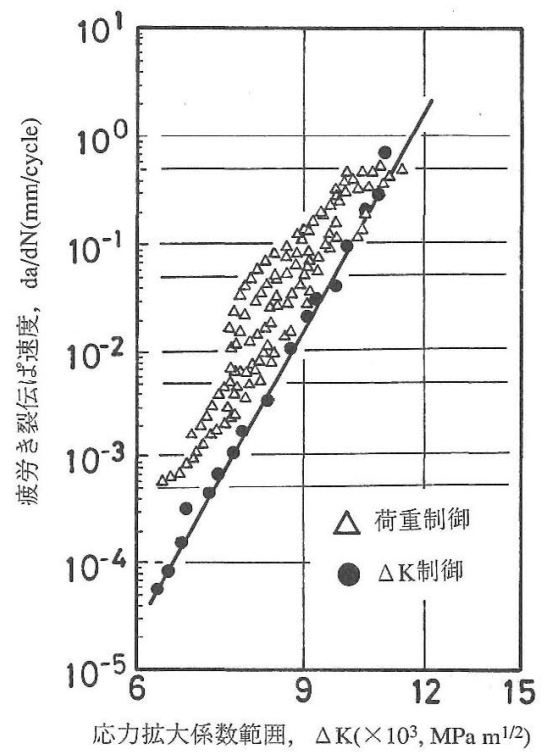

図 3 CSM 材の疲労き裂伝ぱ挙動

度 $d a / d N$ と横軸に応力拡大係数範围 $\Delta K$ との関係結 果である。図中の $\Delta$ 印は CT 試験片による荷重範囲 4.51 5.49MPa の荷重制御デー夕結果，印はテーパ 付き $\mathrm{DCB}$ 試験片による $\Delta K$ 制御デー夕結果である。こ の図より，荷重制御試験結果はバラッキが見られ， $\Delta K$ 制御試駼結果ではそれより良い相関が見られる。これは 本供試材のき裂伝ぱが $\Delta K$ 支配であることを示唆し, この関係は次式(2)のようなパリス則で表わされる。

$$
d a / d N=C(\Delta K)^{m}
$$

ここに，係数 $C$, 指数 $m$ は材料定数である.

また, 静的特性と先の式(1)の $S-N$ デー夕から $d a / d N$ が予測できる報告もある。図 4 中の $d a / d N$ 予 測式は，式(1)と(2)，損傷領域での応力がリガメント幅 $D$ に渡って一定であると仮定, $S / S_{0}=K_{\max } / K_{Q}$ ，ざら に, 単位破断繰返し数当たり $D$ たけ破断すると仮定し て $D / N=d a / d N$ とすることにより誘導される。ここ に, $K_{\max }$ は最大負荷応力での応力拡大係数, $K_{Q}$ はその 材料の静的破壤じん性である。図 4 の CSM P SMC 材 の $d a / d N$ と $K_{\max } / K_{Q}$ の関倸結果上り, 図中に示され た $S-N$ 挙動からの $d a / d N$ の予測結果とよい一致がみ

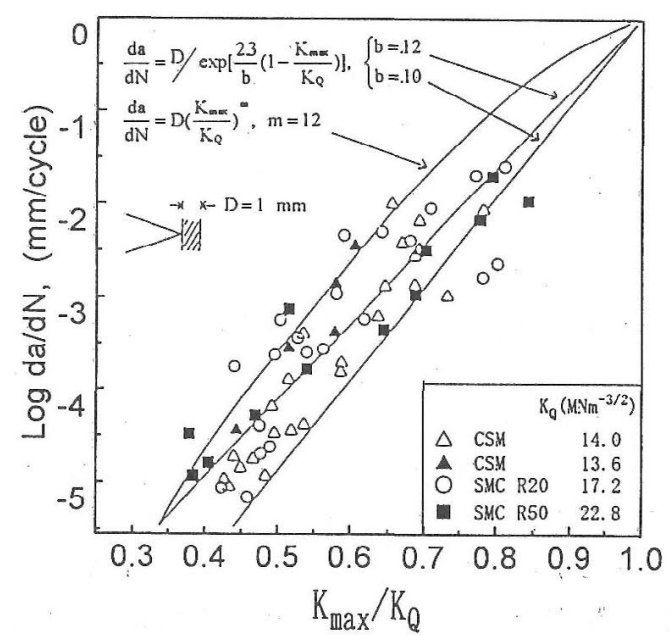

図 4 SMC と CSM 材の疲労き裂伝ぱの実験データ と $S-N$ 曲線からの予测結果との比較
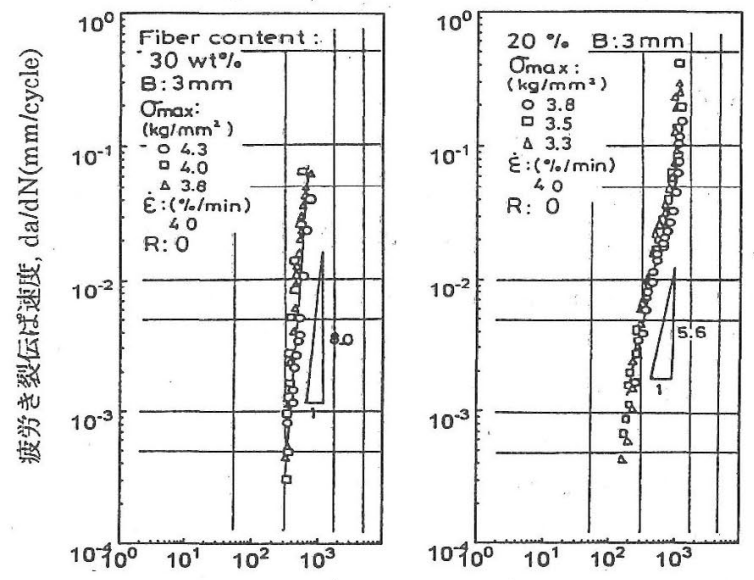

応力拡大係数範囲, $\Delta \mathrm{K}\left(\times 10^{3}, \mathrm{MPa} \mathrm{m}^{1 / 2}\right)$

図 5 射出成形複合材のき裂伝ば挙動

られる。

射出成形での短瀻維強化熱可塑性プラスチック材のき 裂伝ば挙動は, 図 5 のガラス短瀻維強化ポリカーボネー 卜材の繊維含有率 30 と $20 \mathrm{wt} \%$ の引張疲労の一例市と先 の図 3 の CSM 材と比較することからわかるように，バ ラッキが小さく式(2)でよく整理できる。 その指数 $m$ は, $30 \%$ で $8,20 \%$ で 5.6 と比較的高く, 一般に 6 9 9值を とり，また，バルクな熱可塑性プラスチックの多くは， 疲労のき裂伝ぱに対して，敏感に応答することを示し， そのときの $m$ 值は $3 \sim 5$ と言われている。

射出成形材の疲労き裂伝ぱ挙動の他の研究として, 緎 維含有率と瀻維長を変化させた E ガラス強化ポリブチ レンテレフタレート材の引張疲学試験による多数き裂発 生とそれらのき裂進展メカニズムの関係を解明したもの がある。これは, 最初の $1.5 \times 10^{3}$ 回までは初期設定負 荷応力から最大設定負荷応力まで徐々に応力振幅を増加, その後, $1 \times 10^{3}$ 回まで初期設定負荷応力まで減少させ る.この結果, 応力減衰の変化曲線が得られ，この変化 曲線がき裂発生とき裂進展とに関係するとして考察した ものである。また，短繊維強化熱可塑性プラスチックの $\mathrm{CT}$ 試験片による引張疲労の $d a / d N$ 特性を統一的に評 
価しようと試みて提案した評価式があり 、それは， $G$ をエネルギ解放率, $J$ を $J$ 積分とすると, 次式(3), (4) で示され, PMMA や PVC の非強化材とガラス短繊維 強化 PA66 材の実験結果でその妥当性を示したものが ある。

$$
d a / d N=C \cdot(\Delta G)^{m} /\left(G_{c}-G_{\max }\right)
$$

低サイクル，高応力の場合は， $J$ 積分を用いて

$$
d a / d N=C \cdot(\Delta J)^{m} /\left(J_{c}-J_{\max }\right)
$$

さらに, PA6 の非強化材と短繊維強化 PA6 材の引張疲 労の $d a / d N$ に及ぼす成形加工（成形温度と射出速度変 化) 中に引き起こされた微細構造変化 (結晶の変化, ス キン層とコア層の変化）の影響についての研究や反応射 出成形 (RIM 成形) による粉砕ガラス繊維強化 PA6 材 の引張疲労の $d a / d N$ に及ぼすガラス含有量, 繊維長さ などの影響を調べた結果，式(2)により整理でき，その $d a / d N$ は射出成形による強化 PA6 材よりもかなり速 く,これは, 繊維長さの違いによるものとしたものなど がある.

\section{$2 \cdot 3$ 疲労破壊機構}

FRP の破壊のメカニズムは, 一般には母材樹脂割れ, 繊維破断, 連続繊維強化積層型では層間はく離, 短繊維 強化型では樹脂/繊維界面はく離のいずれかにおいて, 初期損傷として発生, その後それらの進展により, 最終 破壊に至る過程をとる. 疲労における短繊維強化型の破 壊では, 疲労損傷の発生が一力所に留まらず数力所で起 こり, 疲労中にそれらが合体し, 主き裂に発展して, 最 終破壊に至る過程をとる. 先に述べた短繊維強化型の疲 労強度やき裂伝ば挙動は, この破壊のメカニズムの差異 により特に顕著に影響される. したがって, 疲労破壊機 構の解明には, 繰返し負荷中のどの時期にどのような破 壊が進行しているかを詳細に知る必要がある。ここでは, その二, 三の研究例を挙げる.

自動車用主要外板部品として開発されたクラス A-SMC や短繊維強化 PET 材の疲労破壊機構の解明に $\mathrm{AE}$ 法を適用して, $\mathrm{AE}$ 波の周波数分布を測定し, 破壊 の特定を試みて, 良い成果を得ているもの, 低サイクル 疲労試験中のひずみ応答解析結果と静的負荷時のひずみ と $\mathrm{AE}$ の関係とにより, 疲労試験中に観測される $\mathrm{AE}$ カウントと疲労寿命の関係を使って, ガラス CSMFRP の低サイクル疲労破壊のシミュレーションを行っている もの, ガラス CSM 強化不飽和ポリエステル材の片側切 欠き試験片を用いて, 引張疲労試験を行い, 損傷の巨視 的様相と試験片のコンプライアンスの変化, さらに, 同 時に計測された $\mathrm{AE}$ 信号の解析および破面解析により, 微視力学的に疲労破壊機構を解明しているもの, 短繊維 強化液晶ポリエステル材の疲労損傷過程を $\mathrm{AE}$ 発生位 置測定法および赤外線温度計をも使用して解明している ものやPA6 で含浸させた厚さ約 $0.1 \mathrm{~mm}$, 幅約 $16 \mathrm{~mm}$ の炭素緎維テープを長さ $13 \mathrm{~mm}$ にカットし, ランダム に散布した CSM 型 CFRP 材の疲労破壊過程を SAM, $\mathrm{SEM}$ および AE 法を用いて解明したもので, この材料 の強化基材の特徵は, 繊維が束状でなくシート状である
ことで, 結果の一部であるが, カットされたシート状の 強化材の範囲を越える損傷の広がりを阻止することなど を得ているものなどがある。

以上, 紹介したように, 短繊維強化複合材の破壊機構 の解明には, $\mathrm{AE}$ 法による研究が多く, これは, リアル タイムで破壊の内部情報が得られるためであり, $\mathrm{AE}$ 法 が疲労破壊機構の解明に一つの有効な方法であることを 示唆しているものである.

\section{3 組み合わせ応力下における疲労特性}

これまでの FRP の疲労に関する研究の多くは, 一方 向にのみ荷重が作用する単純な繰返し荷重下での疲労特 性を対象としている。しかし, 実働荷重下では, 構造物 の各部材に，例えば引張りとねじり荷重が同時に作用す るなど組み合わせ荷重が作用することが一般的で, 単軸 荷重が作用するのはむしろ希である. 構造部材として, FRPのより安全かつ経済的な応用のためには, 従来の 単軸荷重下での疲労特性の把握だけでは不十分で, 多軸 荷重（応力）下での疲労特性を知る必要性は高い。また, その損傷進展メカニズムを明らかにできれば, 一層効果 的な複合方法, 例えば, 積層構成, 順序等に対する指針 が得られるものと思われる。本章では, FRP の組み合 わせ応力下での疲労を取り上げ, 試験方法を中心に, 疲 労寿命予測への取り組み等についても簡単に述べる.

\section{$3 \cdot 1$ 組み合わせ応力下での疲労試験}

負荷方法 図6(a)は一方向単層板が互いに直交して積 層されたクロスプライ材あるいは織物強化材を用いた FRP の微小要素の模式図で, マク口的に典型的な直交 異方性を示す：図中，1，2 はそれぞれ材料主軸を表す. このような FRP の組み合わせ応力下での疲労特性を考 える場合, 材料主軸方向の応力 $\sigma_{1}, \sigma_{2}, \tau_{12}$ とそれらの組 み合わせが注目される. 図 $6(\mathrm{~b})$ に示す Off-axis 試験片 に, 試験片長手方向（ $x$ 方向）に単軸荷重を加えても材 料主軸方向から見れば組み合わせ応力が作用することに なる.この場合, 応力の組み合わせ比 $\left(\sigma_{1}: \sigma_{2}: \tau_{12}\right)$ は Off-axis angle $\theta$ に依存し，これらを任意に定めること ができない. Ellyin と El-Kadi は組み合わせ応力下で の疲労寿命予測モデルを提案しているが, モデルの検証

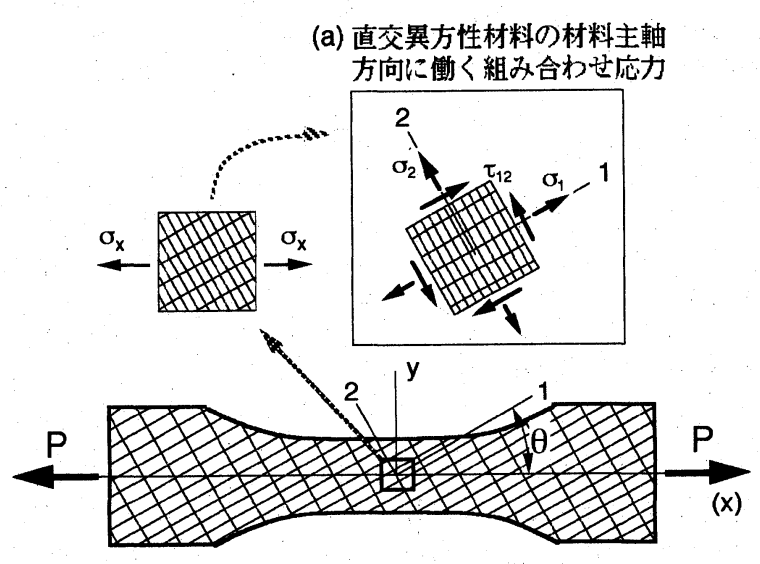

(b) 単軸引張り荷重を受けるOff-axis 試験片

図 6 直交異方性材料と組み合わせ応力 


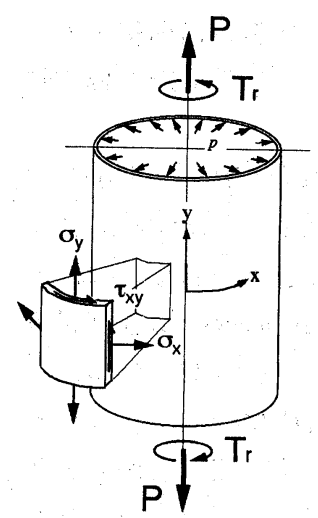

(a) 薄肉円筒試験片

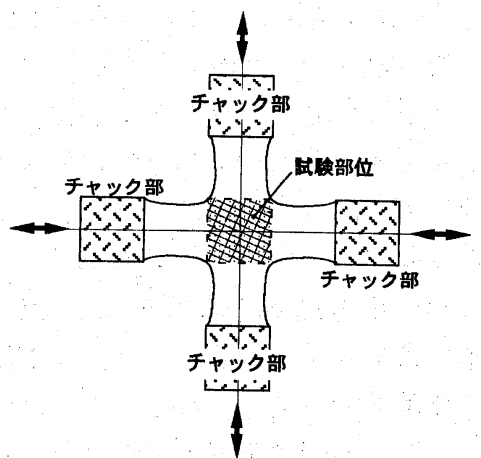

(b) 十文字試験片
図 7 多軸応力下での疲労試験片形状

には Off-axis 試験片による疲労試験結染を用いており, この点，検証が不十分と言える.

\section{試験片と負荷経路 材料に均一で任意の組み合わせ多}

軸応力を作用させることのできる試験片としては図 7 (a) に示寸薄肉円筒試験片がある．軸方向に引張り/圧縮荷 重，軸迴りにねじりモーメントおよび内圧を同時に作用 させれば，任意の組み合わせ応力を材料に加えることが できる，FRPの組み合わせ応力下での疲労に関するこ れまでの研究例の多くは薄肉円筒試験片を用いている. この場合, 引張り/圧縮一内圧执よび引張り/圧縮一ねじ り荷重が加えられ，破断までの繰返し数 (疲労寿命) が 求められる。このとき, 各負荷波形は正弦波または三角 波である，多軸応力下では，材料の受ける応力の変化は 単軸荷重下に比べてはるかに複雑になる。例えば，直交 異方性材料に 3 軸応力 $\left(\sigma_{1}, \sigma_{2}, \tau_{12}\right)$ が作用する場合を考え る. 図 8 のように最終 (最大) 組み合わせ応力状態が $S$ 点の場合, 比例負荷では直線状に応力が作用する. しかし，先に $\sigma_{1}$ を加え，その後 $\sigma_{2}$ を加えても最終応力 状態は比例負荷の場合と同じである. 先に $\sigma_{2}$ を加え, その後 $\sigma_{1}$ を加えることもできる．母材クラック，瀻維 /母材間のはく離や層間はく離により FRP 中の疲労が 進展することを考えれば，最終応力状態が同じでも，負 荷経路が異なれば疲労損傷蓄積の様子が異なり，ひいて は負荷経路は寿命にも影響する。 T 点に至る場合でも 同様である．R 点に向かう単純な応力経路の組み合わ せ経路は 10 以上もある。ささらに，上り複雑な経路も考 えられる。一定組み合わせ応力疲労試験といっても, 多 軸応力下での疲労特性の相互比較, さらに疲労メカニズ ムを考えるに当たっては負荷経路を必ず考慮する必要が ある。

薄肉円筒試験片以外に，図 7 (b)に示す十文字試験片が FRP の組み合わせ荷重疲労試験に用いられる可能性が ある。この場合も，Off-axis 試験片を用いるなどによ り組み合わせ応力をある程度任意に定めることができる しかし，コーナ部での応力集中により疲労破壊する恐れ のあることから，試験片中央に円孔やき裂を有する試験 片以外では破壊にまで至る疲労試験は難しい．

なお，各組み合わせ応力が同じ值でない場合，比例負

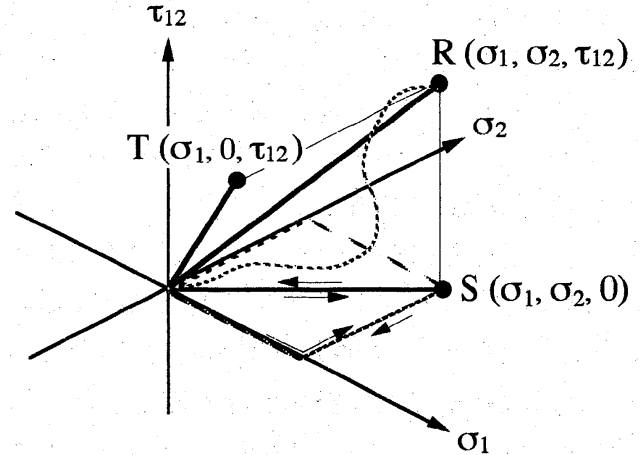

図 8 組み合わせ応力疲労試験における種々の負荷経 路

荷で組み合わせ応力を生じさせるためには，各荷重波形 として正弦波を使うことができないことを強調しておき たい，正弦波を使った場合には，図 8 上で応力経路は直 線とはならない。比例負荷のためには, 荷重波形として 三角波を用いなければならない。

\section{$3 \cdot 2$ 組み合わせ応力下での FRP の疲労特性と損傷 進展}

疲労データの整理単軸荷重下では, FRP の疲労特 性は $S-N$ 曲線に代表される。この場合, $S$ (応力) 軸 として最大応力あるいは応力振幅を用いるのが一般的で ある。一方，組み合わせ荷重下では，引張りノねじり試 験の場合のように 2 軸疲労試験でも代表的には二つの応 力が存在する．そのため, $S-N$ 曲線をどのように表示 すればよいのか注目される。

Owen らૅはマットGFRP の薄肉円筒試験片を用い, 比例負荷により軸方向力と共に内圧を試験片に加え, 定 応力振幅で疲労試験を行った。 2 軸組み合わせ応力下で の FRP の疲労に関する研究で, 彼らの研究は最も初期 に位置づけられる。試験片には常に主応力 $\left(\sigma_{p 1}, \sigma_{p 2}\right)$ が 作用する. 疲労試験結果は，疑似等方性材料として最大 主応力 $S$ と破断もしくは疲労ダメージの開始までの繰 返し数により，いわゆる $S-N$ 曲線としてまとめている また， $10^{3}, 10^{5}$ など特定の寿命に対する包絡面も調べて いる。しかし，疲労メカニズムを言及するまでには至っ ていない。

Francis らは試験片中央に円孔を一個有する円筒 CFRP 試験片の引張り／ねじり荷重による疲労試験を 行っている. 結果はそれぞれの応力（引張り, せん断応 力）を縦軸にとった $S-N$ 曲線で整理した．任意の組み 合わせ応力比 $\alpha\left(=\sigma_{1}: \tau_{12}\right)$ での疲労寿命を予測するため, Hill の静的強度則をそれぞれの疲労寿命（例えば， $N$ $\left.=10^{4}\right)$ に当てはめ, 次式の有効性を検討している.

$$
\begin{gathered}
\frac{\sigma_{1}{ }^{2}}{F_{1}(N)^{2}}-\sigma_{1} \cdot \sigma_{2}\left(\frac{1}{F_{1}(N)^{2}}+\frac{1}{F_{2}(N)^{2}}\right) \\
+\frac{\sigma_{2}{ }^{2}}{F_{2}(N)^{2}}+\frac{\sigma_{6}{ }^{2}}{F_{6}(N)^{2}}=1
\end{gathered}
$$

ここで, $\sigma_{6}=\tau_{12}$ である. $F_{1}(N), F_{2}(N)$ および $F_{6}(N)$ は, 各材料主軸方向の単軸荷重下での寿命 $N$ における最大 繰返し垂直およびせん断応力である. 彼らによれば，引 
張り /せん断組み合わせ応力下では式(5)によって予測さ れた疲労寿命が実験結果とよく一致するとしている.こ の場合，材料主軸方向の単純引張りと純せん断に対する $S-N$ 曲線がわかっていれば, 任意の組み合わせ応力比 $\alpha$ における疲労寿命が予測できることになる. その後, 比例負荷, 一定応力振幅の組み合わせ応力下における疲 労寿命予測に対する同様なアプローチは数多く試みられ ている，すなわち，Tsai-WuやHoffman 則など，任意 の疲労寿命における破壊包絡面が静的破壊規準に適合す るかどうか調べられている, Owen and Rice がガラス 布を強化材とするFRP について, 疲労包絡面に対する 各種の静的破壊規準の適合性を調べたところ，次式で示 されるNorris の変形エネルギ規準が実験結果と最も適 合するようである.

$$
\frac{\sigma_{1}{ }^{2}}{F_{1}(N)^{2}}-\frac{\sigma_{1} \cdot \sigma_{2}}{F_{1}(N) F_{2}(N)}+\frac{\sigma_{2}{ }^{2}}{F_{2}(N)^{2}}+\frac{\sigma_{6}{ }^{2}}{F_{6}(N)^{2}}=1
$$

極低温下でのガラス布強化 FRP の引張り／ねじり疲労 試験を行ったWang らの場合も, 疲労実験データはは じめ引張りおよびせん断応力を規準とするそれぞれの $S-N$ 曲線で整理している. その後, 組み合わせ応力に 対する代表（または，相当）応力として八面体せん断応 力 $\tau_{\mathrm{oct}}$ を用いて $S-N$ 曲線の整理も試みている. 繊維方 向に対して強度の異方性を有する FRP にこの種の相当 応力を導入する明確な理由が不明であり，FRP の疲労 評価に $\tau_{\mathrm{oct}}$ を用いることは適切でない，彼らは各荷重方 向の剛性低下も同時に測定している。 デー夕数は少ない が，疲労寿命のみならず剛性低下に対しても応力の組み 合わせの影響のあることが示された測定結果は興味深い. しかし，データが十分整理されるまでには至っていない。 CFRP KFRP を対象とする組み合わせ応力下での疲 労試験も見られるが，単に疲労特性を提示するだけで， 疲労メカニズムや寿命予測への積極的な試みは少ない.

多軸応力下における FRP の疲労に関する研究の多く は, 単軸荷重下での $S-N$ 曲線と同様な方法でデー夕を 示し，マクロ的に寿命予測を試みようとしているに過ぎ ないとも言える， $S-N$ データにしても，組み合わせ応 力に適した整理がなされていないように思える。 そこで, 組み合わせ応力比をパラメー夕に絽返し最大応力状態を

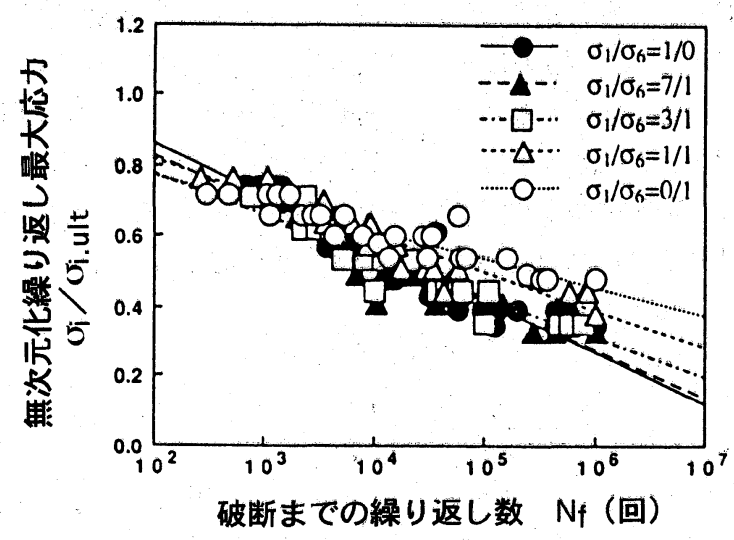

図 9 静的強度により無次元化された引張り／せん断 応力下に拈ける $S-N$ 曲線(平織りガラス布 FRP)
静的組み合わせ応力で無次元化して瘦労寿命曲線を表す 方法が考えられる。このようにすれば疲労寿命曲線を統 一的に取扱うことができる.

図 9 は平織りガラス布で強化された FRP の引張り せん断組み合わせ応力下での無次元化された $S-N$ 曲線

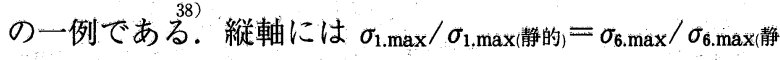
的をプロットした。この場合， $S-N$ 曲線の傾きは組み 合わせ応力比 $\alpha$ の影響を少し受けるものの，全体に一 本の帯で表現し得る。一方, 同 FRP について組み合わ せ荷重下で引張り/ねじり荷重の順序, 組み合わせを変 えると, 疲労の進展と共に奇妙な応力一ひずみ $(S-S)$ 曲 線を描くことが見出された。 せん断側では逆 $S$ 字曲線 となる。繰返し数の増加とともに，その $S$ - $S$ 曲線にお けるヒステリシスが顕著となる。 また, 引張り応力と連 携し, せん断応力の正, 負それぞれの時にループを描く. 特に興味深い現象は, 引張り側において個々の $S-S$ 曲 線はほぼ線形であるが, せん断応力の有無, 正負によっ て傾きが異なってくることである，その結果，記録紙上 には複数 $(2-3$ 本) の $S-S$ 曲線が描かれる。これは, 強化繊維に垂直な方向の引張応力によって生じた母材ク ラック，繊維／母材間のはく離などの損傷がせん断応力 と組み合わされて縦・横繊維にいわば自かけの Off-axis angle を発生させ，剛性を低下させるためであ る.このような, 相互作用は組み合わせ応力下でしか起 こらない.

疲労寿命予測平織りガラス布 FRP の場合, 疲労の 進展とともに組み合わせ応力比に応じて繊維と傾いた方 向に母材クラックが生じる.これらのクラックは主応力 方向にある程度依存するが，繊維の方向の影響も受ける. 軸方向に対して斜めに生じる母材クラック，横繊維のみ ならず縦繊維にも生じる繊維束内の割れの二つが組み合 わせ応力下における特徴的な疲労損傷形態である。それ ぞれの応力に対する見かけの剛性低下も応力の組み合わ せに影響されるが, 繰返し数に対する剛性の減少傾向は いずれの組み合わせ応力比でも同じである。.さらに，同 じ組み合わせ応力下でも, 疲労強度や剛性低下に代表さ れる疲労損傷の進展はせん断応力の方向, すなわち, 片 振りか (Type 1) 両振りか (Type 2) に強く影響され，せ

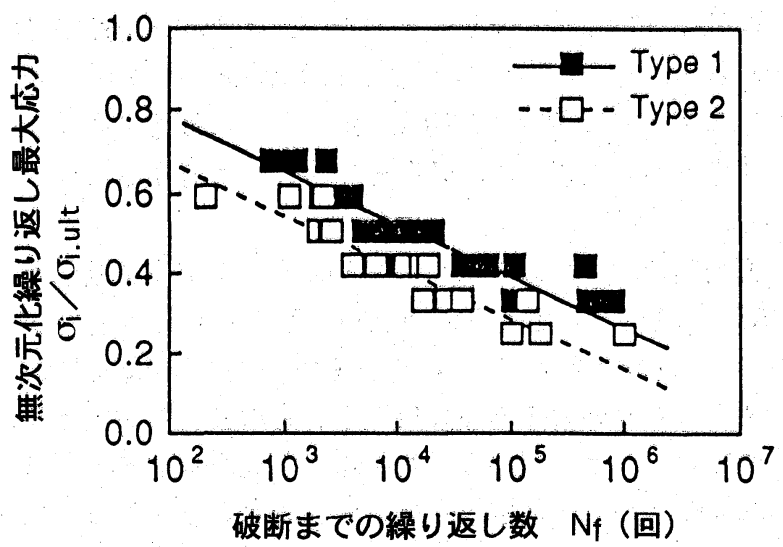

図10 疲労特性に及ぼすせん断応力波形の影響（平織 りガラス布 FRP) 
ん断応力が両振りでは, 図10に示すように疲労寿命が極 端に短くなる。 このことは, 組み合わせ応力下でも, 最 終的にFRPの疲労破壊が繊維の破断によりもたらされ るとしても，繊維の損傷にせん断応力の影響の強いこと が示唆されている.しかし, 詳細な疲労メカニズムにつ いては今後明らかにされなければならない課題である。

これまでの組み合わせ応力下での疲労寿命予測は, 例 えば，単軸引張りや純せん断試験などがら得られた $S-N$ 曲線を基に，静的破壊規準を疲労破壊包絡面にま で拡張することによってなされてきた。しかし，負荷経 路が複雑に存在し得る組み合わせ応力下では，この種の アプローチに自ずと限界がある。本質的に不均質で, 繰 返し数の進展と共に各地で同時多発的に微小内部損傷が 発生, 進展, 蓄積し, 破壊に至る FRPでは, 損傷力学 的アプローチによりその劣化を取扱うのが適切であると 考えられる：また，平織りガラス布 FRP について，組 み合わせ応力比が異なっても，繰返し数に対する剛性の 低下傾向に大きな違いが認められなかったことからこ のような傾向を示すFRP では組み合わせ応力下でも剛 性低下を疲労損傷を推し量る指標にできる可能性がある. 森田らは単軸荷重下での FRPに対する損傷力学的アプ ローチを組み合わせ荷重下にも拡張し, 引張り/せん断 組み合わせ応力下での平織りガラス布 FRP の疲労寿命 の予測を試みた。 その結果, 単軸引張りおよび純せん断 応力下での損傷進展曲線（それぞれの剛性低下の測定結 果から求める) から実用的な精度で組み合わせ荷重下で の疲労寿命が予測できた。

上述の手法によれば，垂直応力による損傷とせん断応 カによる損傷の二つを別個に扱うため, 本来, 材料に対 して一義的に定めら机るべき疲労寿命曲線が複数存在す る（森田らの例では 2 本）という不合理が生じる。いま， 内部損傷を応力およ。びひずみと同様 2 階のテンソルと考 えると, その固有値の中, 最大の值を主ダメージとして, いずれの組み合わせ応力比においても疲労寿命を一義的 に定めることができる。 この方法は平織りガラス布 FRP の疲労試験結果と比較して, 妥当であることが確 かめられており, 今後, 多軸応力下での疲労寿命予測に も拡張できることが期待される。

$$
4 \text { おわりに }
$$

航空・宇宙関係の構造材料として注目された連続繊維 系 FRP の研究が盛況のため, 短繊維系 FRP の研究は 一時低調であったように思われる。しかし，最近，高性 能熱可塑性樹脂がコスト面の問題を克服しつつあり, 環 境問題から材料のリサイクルの必要性なども高まり, 熱 可塑性樹脂の利点を有する短繊維系 FRP が重視されて いる.これらの材料が準構造用のみならず，構造用材料 としても幅広く用いられるためにも改めて，その疲労特 性を理解する必要性は高く, 地道な研究の推進が期待さ れる。

FRP の疲労損傷として, 微小き裂を考えた場合, 応 力の組み合わせにより，開口しない場合もある。また， き裂先端でのモードも異なる. さらに, 最終応力状態が
同じでも応力経路により負荷途中き裂先端の受ける負荷 の状態 (モード) は䔬なる。これらを背景とすれば, 組 み合わせ応力下での FRP の疲労評価に本文で述べた損 傷力学的アプローチを試みるとしても，今後は微視的観 点からマイクロメカニクスと連携して形態の異なる多数 の微小き裂の発生・成長を取扱い，寿命評価に反映して いく必要がある。

\section{参考文 献}

1) D. Dew-Hughes and J. L. Way, Composites, 2, 167 (1973).

2) M. J. Salkind, ASTM-STP 497, 143 (1972).

3) H. T. Hahn, ASTM-STP 674, 383 (1979).

4) K. L. Reifsnider, "Fatigue of Composite Materials", Comp. Mater. Series, Vol. 4 (1991) Elsevier.

5 ) T. Tanimoto,S. Amijima and H. Ishikawa, Proc. of Third Conf. on Mechanical Behaviour of Materials, 3, 207 (1979).

6 ）強化プラスチックス技術協会編, 強化プラスチックハンド ブック, p.110 (1975) 日刊工業新聞社.

7 ) K. L. Reitsnider, "Fatigue of Composite Materials", Comp. Mater. Series, p. 231 (1991) Elsevier.

8 ) 古江治美, 平野一美, 材料, 41, 232 (1992).

9) R. Boukhill, R. Gauvin and M. Gosselin, Inter. SAMPE Sympo. and Exhibi. Book 2, Vol. 34, 2096 (1989).

10) S. W. Carswell, ASME Petroleum Division, 24, 105 (1988).

11）西谷弘信, 野口博司, 金 允海, 山口照敬, 材料, 41, 740 (1992).

12）秋庭義明, 原田昭治, 柳生佳則, 中野雅弘, 材料, 41, 1285 (1992).

13）山田章義, 兼本道成, 浜 善文, 強化プラスチックス, $\mathbf{3 5}$, 434 (1989).

14）鈴木 恵, 中西 博, 岩本正治, 山本泰裕, 近藤昌樹, 材 料, 31, 1150 (1982).

15）鈴木 恵, 中西 博, 岩本正治, 山本泰裕, 材料, 32,82 (1983).

16）鈴木 恵, 岩本正治, 梶屋俊幸, 日本機械学会論文集, 43, 3621 (1977).

17) W. Janzen and G. W. Ehrenstein, Kunststoffe-German Plastics, 81, 31 (1991).

18) C. L. Chow and T. J. Lu, J. of Rein. Plas. and Comp., 10, 58 (1991).

19) J. K. Kocsis, Composites, 21, 243 (1990).

20) D. C. Martin, G. E. Nobak and M. G. Wyzgoski, J. Appl. Poly. Sci., 37, 3029 (1989).

21）鈴木 恵, 中西 博, 岩本正治, 矯 桂琼, 小池 清, 伊 村 真, 重水 聡, 自念榮一, 材料, 36, 1402 (1987).

22）鈴木 恵, 伊村 真, 岩本正治, 自念㮡一, 藤原照彦, 日 本機械学会論文集 A-55, 1081 (1989).

23）福田武人, 逢坂勝彦, 藤井太一, 高田政宏, 材料, $\mathbf{3 7}, 15$ (1987).

24）関根英樹, 根村雅晴, 日本機械学会論文集 A-55，756 (1989).

25) T. Weng, A. Hiltner and E. Baer, J. of Composite Mate- 
rials, 24, 103 (1989)

26）自念第一, 平井幹也, 日本機械学会論文集 A - 58, 1581 (1991).

27) F. Ellyin and H. El-kadi, Composite Structures, 15, 61 (1990).

28) J. Awerbuch and H. T. Hahn, ASTM STP 723, 243 (1981).

29) M. J. Owen and M. S. Found, Faraday Special Discussions of the Chemical Soc., 2, 77 (1972).

30) P. Francis, D. E. Walrath, D. F. Sims and D. N. Weed, J.C. M., 11, 488 (1977).

31) Z. Hashin, Int. J. Fracture, 17, 2, 101 (1981).

32) Z. Fawaz and F. Ellyn, J. C. M., 28, 15, 1432 (1994).

33) M. J. Owen and D. J. Rice, Composites, 12, 13 (1981).

34) S. S. Wang, E. S.-M. Chim and D. F. Socie, Trans. of STM, J. Eng. Mate. and Tech., 104, 128 (1982).
35) S. S. Wang, E. S.-M. Chim and D. F. Socie, ASTM STP 787, 287 (1982).

36) E. Krempl, J. Am. Helicopter Soc., 33, 3, 3 (1988).

37) S. Amijima, T. Fujii and M. Hamaguchi, Composites, 22, 4, 281 (1991).

38）藤井 透, 網島貞男, 林 釩, 佐上太介, 日本機械学会 論文集 A -58，554，1751（1992）。

39) S. Amijima, T. Fujii and T. Sagami, J. Energy Resources Tech., Trans. of ASME, 113, 235 (1991).

40). 藤井透, 林釷, 森田祐介, 日本機械学会論文集 $\mathrm{A}$ -60, 571, 650 (1994).

41）森田祐介, 林 釷, 藤井 透, 日本機械学会論文集 A61, 583, 493 (1994).

42) H. Kawakami, T. Fujii and Y. Morita, J. Reinforced Plastics and Composites, 15, 183 (1966). 